\title{
Redeeming the Habitus: A Christian Sociological approach to Embodiment in Sport
}

Mike Tyler

miketylersport@gmail.com

University of Worcester, Stourbridge, West Midlands, UK

$\&$

Tom Gibbons

Department of Psychology, Sport \& Exercise, Teesside University, Middlesbrough, UK

\begin{abstract}
The human body is of central concern in both the sociology of sport and in Christianity. This paper seeks to respond to exclusively secular explanations of embodiment, which are insufficient for explaining the role and significance of religion in society broadly, and in sport particularly. Affirming an explicitly Christian understanding of the body, the paper shows how the Bourdieusian framing of embodiment - habitus - is amenable to the incorporation of the historic theological uses of the habitus concept. It will be argued that there is no need to jettison either this theological groundwork, or the theoretical insights of sociology in making sense of embodied persons in sport. Instead a more rounded conceptual tool will be produced. Finally, in conclusion, some thoughts will be offered as to the future application of this 'redeemed' habitus in the sociological study of sport and religion.
\end{abstract}

\section{Introduction}

The secularization thesis remains one of the key explanatory paradigms for the emergence and form of late modern capitalist societies (Bruce 2002, 2011; Casanova 1994, Neuhaus 2009, Taylor 2007). Its origins lie substantially in the work of Max Weber, who's Protestant Ethic 
and the Spirit of Capitalism (1971) identified a process by which rationalization came to be the driving force of socio-economic activity. Weber clearly placed Christianity, specifically Calvinist Protestantism, at the centre of his thesis in which he argued that the faith-initiated practices of believers were so materially fruitful that they were copied by others. In time, these practices became encoded as the 'spirit of Capitalism'. Somewhat paradoxically, despite the central place given to religion and religious ideas by Weber in his own analysis of the development of modern societies, the tendency of subsequent thinkers in the social sciences has been to permit these same factors to sink into the theoretical background. It has been suggested by Beckford (1989) that religion was increasingly marginalized in the disciplines which make up the social sciences as they progressed through the 20th century. However, the explanatory power of the secularization thesis has been called into question in recent decades as sociologists have sought to make sense of the far-reaching events of the $9 / 11$ terrorist attacks on New York and the subsequent rapid reemergence of the topic of religion in the 'public sphere' (Berger 1999; Casanova 1994; Gorski and Altinordu 2008; Habermas 2006). Habermas (2006) argued that secular and religious citizens have a duty to engage in dialogue within the public sphere in the interests of reaching a liberal consensus on certain issues. According to Turner $(2014,774-775)$, there has been a 'revival of the sociology of religion in the late 20th and early 21 st century' which is 'associated with growing recognition of the importance of religion in public life' (see the paper by Gibbons, Watson and Mierzwinski in this volume for more on the concept of 'public religion'). This sea change has even led some writers to tentatively postulate the notion of a 'post-secular turn' (Habermas and Reemtsma 2001; McLennan 2007).

However, before grasping at the possibilities offered by this 'turn', two things must be noted. First, it is apparent that the growth in interest and renewed focus on religion in the parent discipline has not yet been replicated in the sociology of sport sub-discipline. Shilling and 
Mellor $(2014,350)$ argued that the topic of religion has been 'marginalized' in sociological analyses of sport over the past two decades. Furthermore, notwithstanding the growing treatment of religion in academic literature, in earlier work Mellor and Shilling (2010) argued that that the ways in which religion has been deployed as an explanatory factor in making sense of the social have been inadequate. They suggest that the enduring methodological default position of sociology, as a discipline, remains to ascribe to religion the position of dependent variable. That is to say, while class, 'race', and gender inter alia are (methodologically at least) taken to be constitutive of society, religion is more often theorized as being constituted by society. For Mellor and Shilling (2010), this is a problematic feature of a stringent adherence to secularist explanations of the social. McLennan $(2015,127)$ identifies this standpoint as follows:

From a seemingly agreed empirical matter of historical process, the idea that religion steadily declines in salience and strength in modern industrial society is now held by many to be a meta-theoretical projection of sociology's secularist values.

The continued global relevance of religion, its persistence in spite of secularizing processes, and the difficulty faced when one attempts to map it onto existing analytical frameworks of sport, all point to the need for a rethinking of this subsidiarity. Consequently, the need to reconceptualize sport as a sacred phenomenon has previously been noted by Shilling and Mellor (2014) in their critique of published work within the sociology of sport sub-discipline. Nevertheless, these authors argue that there is no need to wholly reject the sociological tradition in addressing the absence of religious ideas therein. Shilling and Mellor $(2014,352)$ go on to develop what they describe as 'a novel theoretical account of sport's centrality to social life, attentive to its secular, religious and sacred aspects' by using the work of two of sociology's 
‘founding fathers', Émile Durkheim and Max Weber. The former argued that 'religion' and the 'sacred' persist in modern societies playing a role in maintaining social order; whereas the latter suggested that the increasing rationalisation of modern societies diminished the significance of both. In previous work, Mellor and Shilling (2010) have shown the value of Durkheim's sociological theory, and their use of body pedagogics, as a means for thinking about religion as a social fact. This is another means by which the dominance of secular explanations has been challenged.

Providing a precise definition of religion is problematic. Given that 'the search for an essence ends up in vagueness' (Smart 1989, 10), it is not our intention to enter into debate on the precise delimitations of the concept, acknowledging rather the lack of consensus and 'promiscuous' multiplicity of uses (Jirásek 2015, 290). Instead we will employ the term rather more pragmatically to refer to the multi-dimensional range of human individual and communal experiences, practices, beliefs and dispositions vis-à-vis the transcendent sacred (Smart 1989). This pragmatic ambiguity is deliberate since in our definition we seek to accommodate both formalized institutional structures (such as priesthood), rituals and rites (such as eucharist, hajj) as well as more dispositional elements of religion such as piety, faith and belief, and the ways of being that these effect. We recognize that many Christians in particular are uncomfortable with framing their Christian faith as a religion per se, preferring instead to speak of their faith in the language of relationship and spiritual union with God through Christ. For example, Keller (1999) has argued that Christianity is 'true spirituality', and rejects the religion epithet outright. However, in our view what is being rejected is religion very narrowly described by Keller (1999, para.10) as 'a body of fixed doctrine and ethics that one must adhere to in order to acquire rights to blessings and heaven'. We are evidently using the term differently, more pragmatically. Our sense is that our definition of religion is sufficiently broad to accommodate 
Keller's own framing of Christian faith, as true spirituality, as well as the mode of 'religion' which he decries, which we might label 'religiosity'.

In this paper we seek to build upon the work of Shilling and Mellor (2014) through the consideration of a Christian theological perspective. In so doing, we seek to investigate some of the possible causes of the relegation of religion in the social sciences (and correspondingly within the sociology of sport), and to map a way forward which affords it a greater explanatory weighting. It is our contention that there is room for careful modification, adaptation and realignment of many existing sociological concepts which we hope will render them more amenable to religious, even theological, considerations at the epistemological level. In turn, we seek to parallel the trajectory set by Mellor and Shilling (2010) in their analysis of Maussian body pedagogics to show how Pierre Bourdieu's concept of habitus might be conceptualized for a post-secular, theologically-informed investigation of embodiment in sport.

\section{Embodiment}

Sport is about bodies. Players and athletes push themselves to their physical limits in search of success and in pursuit of excellence. Bodies can be overused, misused and even abused in the quest for sporting glory. Sport is an arena of corporeal performance of individual identities which are manifest in a variety of actions and behaviours. These include on-field prayer, elaborate celebrations and pre-game rituals, as well as gestures, symbols and slogans on clothing and, increasingly, tattoos. Sport is also a field of relations between and amongst bodies. Athletes' bodies are constrained, enabled and disciplined, and are susceptible to an array of social forces that combine to shape bodies according to their position in the field. Provided we are 'attentive to its secular, religious and sacred aspects' (Shilling and Mellor 2014, 352), the social scientific study of embodiment in sport potentially becomes an enormously fruitful field of inquiry. 
With this in mind, the human body - the sporting body - would appear to be a valid starting point for any conversation between sociology and Christian theology and more specifically between a sociology of sport and a Christian theology of sport. There are two key points of articulation between the disciplines. First, while the body lies at the heart of the two disciplines, both rely upon a received (and often taken-for-granted) anthropology. Second, both disciplines have often faced similar objections and challenges with regard to their philosophical bases. Indeed, both sociology and Christian theology have at times become entangled with a Platonic-Cartesian dualistic philosophy of humanity, which the sociological concept of embodiment and the theological concept of incarnation have transcended/resolved in similar conceptual ways.

Shilling $(2012,12)$ has argued that historically speaking the body has been an absent presence in sociological writing. That is to say that, while the body has been necessarily discussed, described and deconstructed in treatments of class, gender, disability and other central sociological concerns, the body itself has rarely been treated as a sociological concern. As a consequence of the epistemological basis of the discipline, Shilling asserts that the body has traditionally been seen by sociology as belonging to the natural, pre-social order, and therefore outside of its direct scope or remit. For example, classical sociological thinkers such as Marx, Durkheim and Weber have considered the body in an implicit sense, and more recent scholars such as Goffman and Foucault have acknowledged the body in the form of a social construct or theoretical space. However, Shilling argues that human agency is obscured in such conceptions, because the material body facilitates social action and interaction, and is therefore conceptually irreducible.

Norbert Elias's (1939/2000) work, which accepts a priori the materiality of the body, argues for an historical sociological process acting upon the body, which he called The Civilizing Process. Elias demonstrates how, throughout history, the body became a contested 
space where the human being is increasingly subject to a complex web of social demands, constraints and requirements. While much of Elias's work is pertinent to the present discussion, and has been utilized extensively by numerous sports sociologists (particularly amongst figurational sociologists), it is his use of the concept he termed 'the hinge' to make sense of the way in which the human body operates in the social world, that interests us for the moment. The hinge is, for Elias, the conceptual meeting point between learned (i.e. social) knowledge and unlearned (i.e. pre-social) knowledge, which Elias refers to as 'pre-conscious body knowledge' (Elias 1987, 350-51). The concept permits us to investigate two things. First, to study the body as a social object and artefact rather than confining it to the arena of natural or biological study. Second, to draw conclusions about society, and the individuals acting therein, from the preconscious bodily realm of affect, emotion and spirit.

The Christian Scriptures also place a substantial emphasis on the body. For example, in Genesis (2:7), Moses' account of creation dwells on the formation of Adam from the 'dust', and the inspiration of God's Spirit into that form to create 'a living soul'. In turn, it is common within Old Testament prophecies regarding the Messiah to refer to his corporeality. For example, Zechariah writes; 'they shall look on him whom they pierced' (Zechariah 12:10) and Isaiah tells us that 'by his stripes [i.e. lashes of a whip] we are healed' (Isaiah 53:5). Similarly, the New Testament opens in the Gospel of Matthew with an affirmation of the patrilineage of Jesus Christ, as the fleshly descendant of King David and thus heir of his throne. The Gospel of John tells us that 'the word [i.e. Christ] became flesh' (John 1:14). The Apostle Peter (1 Peter 2:24) centres his discussion of the salvific work of Christ on the cross by affirming that he bore 'our sins in his body on the tree'. The Eucharist itself - as initiated by Jesus and expounded by the Apostle Paul - serves to remind its participants of the bodily death of Christ, and brings the communion of saints together in a physical act, as an eating community (Mellor and Shilling 1997); that is, at the very least, a community in which the body is a constitutive 
element. The Bible repeatedly affirms the human body as valuable and worthy of discussion. Moreover Christian theology also locates the whole embodied person at the centre of a nexus of influences, including - but not limited to - the social, the biological, the psychological and the spiritual.

Like the contemporary sociology of embodiment, Christian theology affirms both the integrated holistic nature of the individual alongside (and as a part of) the social dimension of human being. Both are developed through the discussion in New Testament Scripture, and the subsequent centuries of debate by Christians, on the nature of Christ, who is the incarnate Word of God and exemplar of perfect humanity. The Apostle Paul sums up the embodied nature of Christ thus: 'For in him dwelleth all the fullness of the Godhead bodily' (1 Corinthians 2:9). That is, the 'fullness' of the Godhead - Father, Spirit and Son - are incarnate in the person of Christ. In addition to this, the first chapter of John's Gospel indicates the relational - and therefore social - purpose and consequence of Christ's incarnation: 'And the Word was made flesh, and dwelt among us' (John 1:14b, emphasis ours).

While the theology of incarnation is a different framing of human anthropology to that provided by the sociology of embodiment (and Bourdieu's own understanding of the concept, to which we will shortly turn), it shares an attempt both to emphasize the importance of the body in understanding and shaping the social world and also to overcome the dualism which has characterized both some Christian (specifically Protestant) theology (Hall and Thoennes 2006), as well as much early modern sociology. Beginning with Plato, dualism has been everpresent in philosophical thought. However, one critical problem with mind/body dualism is its failure to adequately explain the role and origin of habit in human lived experience and the relatively stable subconscious predispositions towards certain kinds of actions, emotions and tastes. 
Given that the social sciences have been beset with an uncertainty regarding the nature of the body itself, it is unsurprising that there has also been 'little consensus about how to analyse the subject' (Shilling 2012, 43). Figurational sports sociologist Maguire (2011, 928) moves us in the right direction when he argues that 'at both the theoretical and substantive levels, the biological, psychological and sociological dimensions of human beings are interconnected'. That is to say, Maguire encourages us to study human social experience 'in the round', taking full account of the complexity of influence on human action and interaction. Within the disciplines of theology there is a long tradition of Judeo-Christian anthropology which seeks to achieve the same end: a holistic view of humankind. In keeping with this tradition, we would propose to add the 'spiritual' dimension to Maguire's list as a critically important element of the whole embodied person, and thus of society.

As Watson $(2011,4)$ has asserted with reference to Christian psychology and the study of human identity, it is proper that a Christian sociology also must be 'predicated on the biblical position that all humans are made in the image of God - imago Dei (Gen. 1: 27) and comprise soul, body and spirit (1 Thess. 5: 23)'. In further clarifying this ontological assertion, Watson $(2011,5)$ reminds us of the tri-unity of human being: 'the human-being is thoroughly integrated, though with different aspects'. Needless to say, in what follows, we seek to show how a fuller conceptualization of embodiment might benefit from (specifically Christian) theological input generally, and the Christian concept of the triune nature of human beings in particular. We shall attempt to traverse the somewhat nebulous boundaries between theology and sociology and offer a 'redeeming' of perhaps the most prominent sociological framing of embodiment: Pierre Bourdieu's concept of habitus. Finally, we suggest ways in which this newly-conceived tool might be applied to the field of sport in order to produce a more rounded analysis of the subject in accordance with a biblical anthropology. 


\section{Overcoming Dualism with Habitus: an historical sketch}

Whilst the concept of habitus has been adopted across a range of sociological sub-disciplines, it is not entirely new to theologians. Indeed, a number have used it to investigate both the Godward aspect of human being and the myriad ways in which the whole person learns, cultivates and performs their personhood in awareness of that relation. For example, Carlisle (2013) presents a sketch of the history of the habitus as a concept which bears this out. Here we rehearse her summary to show, in particular, how the concept has been repeatedly used in counteracting varied forms of philosophical dualism, as well as adding a few thoughts of our own.

In responding to Platonic dualism, Aristotle (c. 384-322 B.C.) proffered the notion of hexis (the Greek equivalent to the Latin habitus) as a way of understanding the way in which human beings gain, over time and through conscious rational choice, the ingrained propensity to act in a morally virtuous way. He emphasized the stability of the hexis/habitus, arguing that it was 'exceedingly hard to change' (Aristotle, 1963: 24/Categories 8b26-9, quoted in Carlisle 2013). This interaction between mind (or soul) and body is one of the central themes of the Apostle Paul's theological writings (in the epistle to the Romans in particular), and he provides an early Christian explanation of the role of the Spirit of God in this relationship. Paul identified within humanity a propensity to sin, which underlies Christian thinking on individual human agency. Following the teaching of Paul, and in distinction to Aristotle, Augustine (A.D. 354430) presented a negative view of 'habit', in which he suggested that it ensnared the soul, shackling the person (spirit, soul and body) to a predisposition towards sinful action (Prendiville 1972). In Augustine's view, it was only by the intervention of divine grace that a person's disposition could become virtuous. While Augustine stressed the sinfulness of the habitus, nevertheless he shared with Aristotle the idea of its enduring stability. The dualistic theology of the Manicheans - who taught that the material world (and therefore the human 
body) was inherently evil, while the soul was good - was contradicted by the Augustinian theology of habit (Carlisle 2013).

Medieval scholars, such as Thomas Aquinas (1225-1274), borrowed from the philosophy of Aristotle importing and synthesizing much of his work into Christian theology. According to Carlisle, where Aquinas differs from Augustine, is in his understanding of the freedom of the will. Aquinas found it untenable to believe that the human soul, being so constrained by a sinful habitus, was incapable of virtuous action without the direct intervention of the Spirit of God, positing an 'infused virtue' (Carlisle 2013, 36), which has its origins with God but remains to be enacted (and thereby made habitual) by the will of the recipient. Martin Luther (1483 - 1546) reached back beyond Aquinas to return the discussion on habit to a more (though not entirely) Augustinian framing. Luther's theology of the bondage of the will, which underlies his conception of habit and habitus, leans heavily on Augustinian theology. Luther felt that Aquinas had allowed too much room for the individual human will as a means of effecting a virtuous disposition reasserting the inability of man not only to do good, but even to desire it, without the intervention of the Spirit of God in the form of a freely-given (i.e. unmerited) righteousness.

What we have tried to show from this brief explanation of the progression of the concept of habitus through the ages is that it has almost always been deployed in a theological context. In early modern thought, and even up until the Enlightenment, philosophy (science) and theology are wholly compatible, with the former being handmaiden to the latter (Zakai 2007). However, a seismic shift occurred in the late Reformation period that dethroned theology from its place as 'queen of the sciences', when René Descartes revived philosophical dualism. His maxim cogito ergo sum neatly encapsulates the now-pervasive view of the separation of the mind and the body, as well as the supremacy of the former. The most significant result of Cartesian dualism for the present discussion was the separation of theology and philosophy 
(Goudriaan 2015). Consequently, philosophy - as a rational cognitive pursuit - has enjoyed more than two centuries of intellectual dominance, becoming embedded in Western academic thought.

The disenchantment of the Western world, and the rationalization of Western philosophy meant the ostracizing of Christian theology from the academy as incompatible with Enlightenment praxis. However, the nascent discipline of sociology flourished amidst Enlightenment thinking. It was within this context, for example, that Max Weber produced his Protestant Ethic. Hereafter - and crucially for our thesis - the problems inherent in Cartesian dualism were seldom resolved by theological means, but rather through similar yet secular counter-explanations. In the early years of the social sciences counterbalances to dualistic thinking about human beings were provided through the anthropology of Merlau-Ponty and the phenomenology of Edmund Husserl in particular. Marcel Mauss was perhaps the first of the modern era to develop a thorough-going secular version of the habitus, and although he acknowledged his debt to Aristotle, he eschewed the theological aspects which we have alluded to here (Crossley 2013a; Mellor and Shilling 2014). Paulle et al. (2012) suggest that this secular version of habitus arrived at Bourdieu via Elias. Atkinson (2012) agrees with this assessment, describing Bourdieu's concept of the habitus as similar to that of Elias.

In sum, two key points are worthy of note at this stage. First, it seems that the theological habitus (whichever version we take) lacks adequate explanation of the embodied individual in society, being almost exclusively focused on the God-ward dimension of human being, and his or her individual relationship to the divine. We respond firmly to this limitation with the assertion that 'neither communities nor embodied individuals can be examined in isolation from each other' (Mellor and Shilling 1997, 14). Second, it seems equally clear that the sociological habitus, as a product of the disenchanted academy, is lacking in capacity to explain the embodied individual in faith. Or, at the very least, lacking in capacity to account 
for faith as anything other than a 'dependent variable'. How are we to make sense of the conviction of believers whose accounts of their lived experience in sport routinely incorporate their faith as a critical constitutive element? In bringing these two disciplines together around Bourdieu's habitus our aim is to carry forward our thinking in this regard. Hereafter, we shall seek to outline the key elements of Bourdieu's habitus before attempting to show how his framing enables us to reconcile the theological and sociological components of the fully embodied social being.

\section{Bourdieu's habitus}

Bourdieu's use of the concept of habitus is enormously valuable inasmuch as it synthesizes an array of social influences into a coherent explanatory framework. To this end, it has justifiably become an oft-used device for sociologists across a range of sub-disciplines. In combining strands from the fields of anthropology, psychology, sociology and philosophy Bourdieu was able to show that while a human being is in society, society is also in a human being (Crossley 2013b). The concept is most fully explained by Bourdieu (1984) himself in his seminal work Distinction: A Social Critique of the Judgement of Taste. Beginning with the notion that our primary socialization typically takes place within a particular and relatively confined social milieu, Bourdieu asserts that we take on a whole stock of attitudes, tastes, dispositions, preferences, behaviours, feelings and ideas, which we then come to regard, at a deep unconscious level, as normal. These dispositions are not merely integrated into our psychology, but are also written into (and onto) our bodies. We develop, in Maussian terms, the 'body techniques' which enable us to navigate within, as well as to exert influence over, that milieu. In framing the human being in this way 'the human actor is irreducibly embodied for Bourdieu; located within the world and attached to it, in the first instance, by practical mastery' (Crossley 2013b, 294). The objective structures of society, as well as the structures of religious and 
sporting subcultures, become internalized and ingrained within our personal make-up as 'dispositions', so that our unconscious feelings, emotions and tastes come to reflect and support these existing structures. It is in this way that individuals who have undergone a similar process of socialization come to perform similar 'ways of being'. In time, some dispositions come to be typical of groups which can be said to share a habitus. This, in particular, is one of the key ways in which Bourdieu asserts and explains the class-based nature of Western industrial societies. An individual might feel 'at home' in a certain field of social relations (the bar, the dinner party, the track, the football stadium), because it matches most closely his or her subconscious tastes and preferences, though he or she may not be able to rationally account for these feelings. Bourdieu's own description of this as a 'feel for the game' presages the utility and applicability of the habitus concept in the sociology of sport, which we seek to develop here. Bourdieu argued that the repeated emergence of these ingrained dispositions as behaviours serves to reproduce and reinforce the characteristics of the social field in which the individual moves. New members of the field, through their own socialization (through hazing and initiation rituals, club expectations, etc.), then incorporate these structures simultaneously at conscious and subconscious levels. This reflexive process, at once constituting and constituted, both agentic and structured, individual and corporate, is at the heart of Bourdieu's theory. He writes:

social agents construct social reality, both individually and collectively....The subjective structures of the unconscious that carries out the acts of construction... are the product of a long, slow, unconscious process of the incorporation of objective structures. (Bourdieu 1996, 29) 
Bourdieu has been criticized for failing to provide a sufficient step away from structural determinism in this framing of the habitus (De Jong 2001; Paulle et al. 2012), an accusation perhaps best encapsulated by his own description of the concept as 'a structured and structuring structure' (Bourdieu 1984, 171). While his later writings address this charge, we believe that a Christian understanding of the embodied nature of social being is particularly helpful in attending to this shortcoming. A recognition of the fully embodied being of the human agent, and his or her non-rational and supra-rational dispositions, means that much of the will and power to act in a field of social relations resides with the individual, albeit outside of rational consciousness.

The existing concept of habitus accounts for emotion, irrationality and gut-feel and as such it acknowledges the often non-rational corporeal nature of human experience, behaviour and knowledge. Wacquant $(2014,118)$ in part acknowledges this when, in recommending the habitus as a conceptual tool, he writes that

treating the sentient and skilled organism as fount of both social intelligence and sociological acumen can help historical social science connect with enactive psychology and recover the carnality of action that conventional accounts of social life routinely erase.

With this we agree, but what, we might ask, of the spirituality of action that is routinely erased? Building upon the foundation of a Christian anthropology, it is barely a stretch to incorporate other non-rational or supra-rational elements of being, such as faith, belief and spirit into the habitus, and to hold to these as independent variables. This breadth of potential application renders the concept an extremely valuable tool in the armoury of the Christian sociologist of 
sport, and we will develop this idea in our concluding section. First, however, we attempt to explain why this synthesis has not been attempted previously.

\section{Addressing a secular bias}

We have already described the methodological default of the social sciences more broadly, but here it behooves us to explain the absence of religion in the Bourdieusian conceptual framework of habitus. First, we argue that Bourdieu himself had a 'blind spot' for the depth of structuring power in the field of religion. Second, we suggest that the academy as a secularised institution is disinclined to make a 'way in' for theology. Third, we address the thorny problem of epistemological and ontological incompatibility between the habitus concept and Christian theology.

We have already outlined Bourdieu's idea that objective structures which constrain and enable a person's upbringing serve to produce a distinct habitus. That habitus then acts back upon (and within) the agent to structure their conscious and unconscious interaction with the social world. Thus, if we are to take Bourdieu's concept of habitus seriously, we ought to take his personal habitus seriously. The circumstances and structures of his upbringing may therefore yield insight into the conscious and unconscious reasons for his selection and rejection of topics for study. While there is limited biographical information available about Bourdieu himself - even his Sketch for a Self Analysis (2008), written towards the end of his life, provides few anecdotal details about his upbringing - it is possible to trace some of the wider social circumstances of his youth.

Bourdieu was born in France in 1930, the son of a postal worker and grandson of a sharecropper in the province of Béarn. The school system through which the young Bourdieu progressed had been made secular by law. The separation of church and state (Laïcité) was a key tenet of the French Republic and in 1882, under the Jules Ferry laws, the schools were 
wrested from the control of the Catholic Church. The secular syllabus was into its sixth decade when Bourdieu attended school. According to Verter $(2003,151)$, Bourdieu's reliance on a concept of religion and the church - borne out of his reading of Voltaire and Weber - meant that he consistently thought of religion in organizational and institutional terms 'but not as a disposition'. Dianteill $(2003,544)$ goes as far as to say that: 'For Bourdieu, religion is in fact an object that is, sociologically speaking, nearly impossible'. Even with the development of his habitus concept 'he did not use this to modify significantly the assumptions upon which his earlier analyses were predicated' (Verter 2003, 151). We might excuse Bourdieu to some extent, as his habitus may have left him with a blind spot on religion; a point made by Lamont $(1992,184)$ when she speaks of 'moral boundaries'. However, that subsequent writers have perpetuated this lacuna may hint at a commitment to guarding the boundaries of the discipline from the incursion of faith-based explanations of social phenomena.

Taking into account the thesis of Weber in The Protestant Ethic, and allying it to Bourdieu's suggestion that habitus is - whilst reflexively reproduced - largely consistent over long periods of time, we can argue that a moral or religious element in habitus formation is a key pillar of that structuring structure. We should then expect to see this empirically, and have some means of theorizing its presence in the lived experience of people in societies influenced by the Protestant Ethic. Mellor and Shilling $(1997,11)$ help us at this point:

In certain respects, many contemporary modern bodies continue to share a strong affinity with Protestant bodies and develop in a cultural context which is not so far removed from these conditions as we might like to think. They can also find themselves coping with these conditions of control, order and careful presentation of self via the adoption of a 'disciplined habitus'. 
The argument here is that the prevalent modern habitus is essentially the 'puritan habitus'. Thus, to neglect the importance of religion is to needlessly perpetuate the lacuna at the heart of much of habitus deployment.

Second, subsequent usage of the habitus in a secularized academy has not needed, or perhaps not desired, the acknowledgement of the spiritual in making sense of, let alone partconstituting, human lives and life-worlds (Casanova 1994, Neuhaus 2009). While the dominance of the secular within other fields of science had been called into question (Polanyi 1966), the first clear chink in the secular armour of modern sociology was arguably Habermas' opening up of the social sciences to the moral, and his subsequent conversations with the then Cardinal Ratzinger, who later became Pope Benedict (Habermas 2010).

Third, it is not insignificant that the founding fathers of modern sociology - Marx, Weber, and Durkheim - thought about society from an atheistic standpoint. They were at times openly hostile and antagonistic towards religion, especially in its organized form, and repudiated the suggestion that God might be anything more than a hopeful Feuerbachian projection of man's inherent virtue (Marx et al. 1974). The ontological and epistemological assertions of 18 th century German philosophical rationalism provide the historical backdrop to the emergence of sociology as a discipline. For many of those who followed this backdrop became a bedrock. We reproduce here a quote from Watson and Parker $(2013,6)$ to show that if we read 'Marx' as a metonym for 'mainstream sociology', we recognize immediately our own place in the field:

...if Christian sport scholars choose to dialogue with Marx they must carefully unpick and integrate theory, while holding fast to ontological, epistemological, and anthropological theism. 
In the particular case of the habitus concept however, epistemological and ontological incompatibility is answered neatly by Bourdieu's student Loïc Wacquant (2014) who asserts that habitus is inherently pragmatic in its constitution. He writes 'habitus ... is not an answer to a research question but rather an organized manner of asking questions about the social world' (Waquant 2011, 91). That is to say, habitus needs to be used as a tool, rather than excessively theorized. Pellandini-Simányi $(2014,652)$ suggests that: 'Bourdieu did not mean his arguments to be ontological, but empirical, and, in principle, falsifiable'. Thus, the concept is freed from the dictates of grand theory, and this makes it accessible to those who would, as we do as Christians, hold to ontological and epistemological views that are at odds with the traditional mainstream of sociological thought and praxis (Parker and Watson 2014; Swinton and Mowatt 2006).

\section{Conclusion: Redeeming the habitus for the sociology of sport}

Just as Habermas (2006) suggests that Weber's 'occidental rationalism' is the deviation from the longue durée of human history, so we may consider sociology's preoccupation with the rational to be the deviation from the history of thinking on embodiment. The reinsertion of a spiritual element into accounts of human social behaviour may well be unconventional in the contemporary context, but the longer trajectory of thought on embodiment would allow room for such theorizing. As Christians we recognize and affirm the reality of the spiritual in structuring the lived experience of human beings. As sociologists we acknowledge the real structuring influences of the social fields in which humans exist. We see no reason to jettison either in making sense of the social, but rather seek to synthesize these within an integrated conceptual framework.

Bourdieu's habitus, then, is a helpful point of departure for an explicitly Christian sociology, and a Christian sociology of sport in particular. We propose the application of a 
'redeemed' conceptualization of the habitus, in the first instance to the lived experiences of Christian sportspeople. Following Mellor and Shilling (2010), one reason for our focus on Christian sportspeople is 'the potential utility of analyzing religious body pedagogics might be especially clear in a detailed, empirically rich account of a religion in a specific context and locale' (Mellor and Shilling 2010, 30). We feel likewise about the habitus; the specific context and locale we propose is that of Christian involvement in sport in the UK.

In the field of sport we routinely hear Christian athletes' accounts of the will and leading of God, the felt presence of the Spirit in directing and restraining action and reaction in the sporting and social life. Ward $(2012,64)$ writes, 'in pain, in being physically challenged...the soul becomes keenly conscious of its inseparability from the materiality of the body'. That is to say, that in sport both the carnality and spirituality of action come to the fore, and ask for our attention. What might we learn about society from these embodied experiences? To what extent are they common, or shared? If 'being 'Christian'...is about possessing specific embodied orientations, experiences and outcomes' (Mellor and Shilling 2010, 34), in what ways do these orientations articulate with other elements of the Christian habitus? Tomlinson (2004, 167) suggests 'empirical studies and empirical studies alone have the capacity to identify the balance between the structuring and the structured in any given case'. These questions, and many more like them, deserve further empirical investigation as they are central to identifying the structuring and the structured, and, more broadly, crucial for the Christian sociological understanding of the sporting body.

\section{References}

Atkinson, Mike. 2012. "Norbert Elias and the Body." In Routledge Handbook of Body Studies, edited by Brian S. Turner, 49-61. Oxford: Routledge. 
Beckford, James. 1989. Religion and Advanced Industrial Society. London: Unwyn Hyman.

Berger, Peter. 1999. "The Desecularization of the World: A Global Overview." In The Desecularization of the World: Resurgent Religion and World Politics, Edited by Peter Berger, 1-18. Grand Rapids, MI: Eerdmans.

Bourdieu, Pierre. 1984. Distinction: A Social Critique of the Judgement of Taste. Translated by Richard Nice. Cambridge: Routledge \& Kegan Paul.

Bourdieu, Pierre. 1996. The State Nobility: Elite Schools in the Field of Power. Translated by Lauretta C. Clough. Cambridge: Polity.

Bourdieu, Pierre. 2008. Sketch for a Self Analysis. Chicago: University of Chicago Press

Bruce, Steve. 2002. God is Dead: Secularization in the West. Oxford: Blackwell

Bruce, Steve. 2011. Secularization. Oxford: Oxford University Press.

Carlisle, Claire. 2013. "The Question of Habit in Theology and Philosophy: From Hexis to Plasticity." Body and Society 19(2/3): 30-57.

Casanova, José. 1994. Public Religions in the Modern World. Chicago: University of Chicago Press. 
Crossley, Nick. 2013a. "Habit and Habitus." Body and Society 19 (2\&3): 136-161.

Crossley, Nick. 2013b. "Pierre Bourdieu's Habitus." In A history of habit from Aristotle to Bourdieu, edited by Tom Sparrow \& Adam Hutchinson, 291-307. Plymouth: Lexington.

De Jong, Mart-Jan. (2001) "Elias and Bourdieu: the cultural sociology of two structuralists in denial.” International Journal of Contemporary Sociology 38 (1): 64-86.

Dianteill, Erwan. 2003. "Pierre Bourdieu and the Sociology of Religion: A Central and Peripheral Concern." Theory and Society 32 (5 \& 6): 529-549.

Elias, Nobert. 1987. "On Human Beings and Their Emotions: A Process-Sociological Essay. Theory" Culture and Society 4: 339-361.

Elias, Norbert. 1939/2000. The Civilizing Process (Revised Edition). Oxford: Basil Blackwell.

Gorski, Philip, S. and Ateş Altinordu. 2008. "After Secularization?” Annual Review of Sociology 34: 55-85.

Goudriaan, Aza. 2015. "Descartes, Cartesianism, and Theology." In The Oxford Handbook of Early Modern Theology, 1600-1800. Edited by Ulrich L. Lehner, Richard A. Muller, and A. G. Roeber. Accessed December 22, 2016. doi:10.1093/oxfordhb/9780199937943.013.37.

Habermas, Jürgen. 2006. "Religion in the Public Sphere". European Journal of Philosophy 14(1): $1-25$. 
Habermas, Jürgen. 2010. An Awareness of What is Missing: Faith and Reason in a PostSecular Age. Cambridge: Polity.

Habermas, Jürgen and Jan Philipp Reemtsma. 2001. Glauben und Wissen: Friedenspreis des Deutschen Buchhandels 2001. Frankfurt am Main: Suhrkamp.

Hall, K. Erik. and Elizabeth Thoennes. 2006. "At Home in Our Bodies: Implications of the Incarnation for Embodiment and Christian Higher Education." Christian Scholar's Review 36 (1): $29-46$.

Jirásek, Ivo. 2015. "Religion, Spirituality, and Sport: From Religio Athletae Toward Spiritus Athletae." Quest 67(3): 290-299.

Keller, Tim. 1999. "Religion-less Spirituality”. Christianity Today 20(4), viewed 14 July 2017. $<$ http://www.christianitytoday.com/pastors/1999/fall/914025.html $>$

Lamont, Michèle. 1992. "Money, Morals, \& Manners: The Culture of the French and American Upper-Middle Class." Chicago: University of Chicago Press.

Maguire, Joseph. 2011. "Body matters: theories of the body and the study of sport cultures." Sport in Society 14 (8): 927-936

Marx, Karl, Friedrich Engels, and Christopher J. Arthur. 1974. The German Ideology, 2nd ed, London: Lawrence \& Wishart. 
McLennan, Gregor. 2007. “Towards Postsecular Sociology?” Sociology 41(5): 857-870.

Mellor, Phillip A. and Chris Shilling. 2010. "Body pedagogics and the religious habitus: A new direction for the sociological study of religion." Religion 40: 27-38.

Mellor, Philip A., and Chris Shilling. 2014. "Re-conceptualizing the religious habitus: reflexivity and embodied subjectivity in global modernity." Culture and Religion 15 (3): 275297.

Mellor, Phillip A. and Chris Shilling. 1997. Re-Forming the Body: Religion, Community and Modernity. London: Sage.

Neuhaus, Richard John. 2009. “Secularizations.” First Things, 190:23-28Parker, Andrew and Nick Watson. 2014. "Researching Religion, Disability and Sport: Reflections and Possibilities.” Journal of Disabilities and Religion 18(2):192-208.

Paulle, Bowen, Bart van Heerikhuizen and Mustafa Emirbayer. 2012. "Elias and Bourdieu." Journal of Classical Sociology 12(1): 69-93.

Pellandini-Simányi, Léna. 2014. "Bourdieu, Ethics and symbolic power.” Sociological Review 62(4): 651-674.

Polanyi, Michael. 1966. The Tacit Dimension. New York: Doubleday. 
Prendiville, John. 1972. "The development of the idea of habit in the thought of Saint Augustine." Traditio 28: 29-99.

Shilling, Chris. 2012. The Body and Social Theory. London: Sage.

Shilling, Chris and Phillip A. Mellor. 2014. "Re-Conceptualizing Sport as a Sacred Phenomenon.” Sociology of Sport Journal 31 (3): 349-376.

Smart, Ninian. 1989. The World's Religions: Old Traditions and Modern Transformations. Cambridge: Cambridge University Press.

Swinton, John and Harriet Mowatt. 2006. Practical Theology and Qualitative Research. London: SCM.

Taylor, Charles. 2007. A Secular Age. Cambridge: Harvard University Press.

Tomlinson, Alan. 2004. "Pierre Bourdieu and the Sociological Study of Sport: Habitus, Capital and Field." In Sport and Modern Social Theorists, edited by Richard Giulianotti, 161-172. Basingstoke: Palgrave.

Turner, Brian S. 2014. "Religion and contemporary sociological theories." Current Sociology Review 62 (6): 771-788.

Verter, Bradford. 2003. "Spiritual Capital: Theorizing Religion with Bourdieu Against Bourdieu." Sociological Theory 21(2): 150-174. 
Wacquant, Loïc. 2011. "Habitus as Topic and Tool: Reflections on Becoming a Prizefighter." Qualitative Research in Psychology 8: 81-92.

Wacquant, Loïc. 2014. "Putting Habitus in its Place: Rejoinder to the Symposium." Body and Society 20(2): 118-139.

Ward, Graeme. 2012. "A Question of Sport and Incarnational Theology.” Studies in Christian Ethics 25(1): 49-64.

Watson, Nicholas J. 2011. "Theological and Psychological Reflections on Identity in Sport." Journal of Religion and Popular Culture 23(2): 182-200.

Watson, Nicholas J. \& Andrew Parker. 2013. "A Christian Theological Analysis of the Institutions and Governance of Sport: A Case Study of the Modern Olympic Games." Journal of Religion and Society 15: 1-21.

Weber, Max. 1971. Protestant Ethic and the Spirit of Capitalism. London: Unwin University Books.

Zakai, Avihu. 2007. "The Rise of Modern Science and the Decline of Theology as the 'Queen of Sciences' in the Early Modern Era." Reformation \& Renaissance Review: Journal of the Society for Reformation Studies 9(2): 125-152. 